\title{
Severe haemolytic anaemia due to cold anti-'i' antibodies associated with cytomegalovirus infection
}

\author{
José M. Aguado, José M. Castrillo, Jesús Sanz and Joaquín Serrano' \\ Departments of Internal Medicine and 'Hematology, Fundación Jiménez Díaz, Madrid, Spain.
}

\begin{abstract}
Summary: A 66 year old patient with multiple myeloma and monoclonal cryoglobulinaemia who developed a severe haemolytic anaemia following a cytomegalovirus infection is reported. The presence of a high titre of anti-'i' cold antibody of IgM subclass is demonstrated. Anti-' $i$ ' antibody disappeared when complement-fixation antibody titres against cytomegalovirus decreased. Various pathogenetic mechanisms involved in the development of haemolytic anaemia associated with cytomegalovirus infection are discussed. To our knowledge, this is the first case described in the English language publications associating severe haemolytic anaemia with an anti- 'i ' antibody after a cytomegalovirus infection in an immunocompromised patient.
\end{abstract}

\section{Introduction}

Cold-agglutinin haemolytic anaemia can be seen in three clinical settings: as an idiopathic disease, associated with lymphoproliferative disorders, and together with various infections. ${ }^{1,2}$ Among the latter, Mycoplasma pneumoniae pneumonia is the most usual, followed by infectious mononucleosis due to Epstein-Barr virus. ${ }^{2}$ In the first case, coldagglutinins show anti-'I' specificity, whereas infectious mononucleosis has anti-'i' specificity. ${ }^{3}$

Significantly raised cold-agglutinin titres are frequently found in cytomegalovirus (CMV) infection, ${ }^{4}$ but they rarely produce haemolysis. In this situation, antibodies could have anti-' $i$ '5 or anti- ${ }^{\prime}{ }^{16}$ specificity. As far as we know, the present case would be the second in English language publications in which an anti-'i'-specific cold antibody haemolytic anaemia has been associated with CMV infection. ${ }^{7}$ Compared with the one previously reported, ${ }^{8}$ our patient was immunocomprised, and suffered a very severe haemolytic crisis, without a mononucleosis syndrome.

\section{Case report}

A 66 year old man, with a 6-month history of bone aches, was admitted to our hospital due to a hypercalcaemic crisis. A diagnosis of Stage III multiple myeloma IgG-kappa type (Durie and Salmon classification ${ }^{9}$ ) with a monoclonal cryo-

Correspondence: J.M. Aguado M.D., calle Valdenoja, 28-A, 39012 Santander, Spain

Accepted: 22 November 1989 globulinaemia was made. After early treatment for symptomatic hypercalcaemia, chemotherapy was started using the M2 protocol. ${ }^{10}$ Secondary, anaemia (haemogobin $8.4 \mathrm{~g} / \mathrm{dl}$ ), and leukopenia (leucocyte count $2.5 \times 10^{9} / 1$ ) developed. Two packed red blood-cell units were transfused. Three days later the patient presented high fever and an enlarged spleen was felt. The white cell count was $3 \times 10^{9} / 1$ with $56 \%$ granulocytes $(10 \%$ bandforms), $22 \%$ lymphocytes, and $12 \%$ monocytes. Several blood cultures were negative. On the 25th hospital day fever persisted and a cooling blanket was applied. Shortly afterwards he became stuporous, hypotensive, tachycardic, with a temperature of $38.8^{\circ} \mathrm{C}$, without meningism nor focal neurological signs and jaundice was noted without evidence of gastrointestinal bleeding Haemoglobin level was $4 \mathrm{~g} / \mathrm{dl}$ (it was $10 \mathrm{~g} / \mathrm{dl}$ the day before). Total bilirubin was $68.4 \mu \mathrm{mol} / 1$, and conjugated bilirubin was $27.4 \mu \mathrm{mol} / 1$, the lactic dehydrogenase was $513 \mathrm{mU} / \mathrm{ml}$ (normal up to $200 \mathrm{mU} / \mathrm{ml}$ ), and hepatitis B surface antigen was negative. Several packed red-blood-cell units were administered with general improvement, although fever persisted. Next day haemoglobin was 4.6 $\mathrm{g} / \mathrm{dl}$, and there was haemoglobinuria ++ .

Immunohaematological findings are shown in Table I, Direct Coombs' antiglobulin test, using cold washings with anti-IgM, anti- $\mathrm{C}^{\prime}$, and anti-IgA sera was positive, but it was negative when anti-IgG, anti- $\mathrm{C}_{3 \mathrm{~d}}$ and anti- $\mathrm{C}_{3 \mathrm{~b}, 3 \mathrm{~d}, 4}$ sera were used. Serum gave a strong positive reaction with human cord and adult human 'I-' erythrocytes, but it was weakly reactive with adult human ' $I+$ ' erythrocytes. Anti-' $i$ ' antibodies showed a thermal amplitude of 
Table I Immunohaematological and serological findings

\begin{tabular}{|c|c|c|c|c|c|c|c|c|c|}
\hline \multirow{3}{*}{$\begin{array}{l}\text { Time after } \\
\text { admission } \\
\text { (weeks) }\end{array}$} & \multirow{3}{*}{$\begin{array}{l}\text { Haemoglobin } \\
\quad(\mathrm{g} / \mathrm{dl})\end{array}$} & \multicolumn{6}{|c|}{ Titre of indirect antiglobulin test } & \multirow{3}{*}{$\begin{array}{c}\text { Direct } \\
\text { Coombs' } \\
\text { antiglobulin } \\
\text { test }\end{array}$} & \multirow{3}{*}{$\begin{array}{c}\text { Anti-CMV } \\
\text { titre }\end{array}$} \\
\hline & & \multicolumn{2}{|c|}{$4^{\circ} \mathrm{C}$} & \multicolumn{2}{|c|}{$22^{\circ} \mathrm{C}$} & \multicolumn{2}{|c|}{$37^{\circ} \mathrm{C}$} & & \\
\hline & & anti- 'i' & anti- $T$ ' & anti- ' $i$ ' & anti- $' T '$ & anti- ' $i$ ' & anti-' $I$ & & \\
\hline 4 & 4 & $1: 128$ & 1:8 & $1: 32$ & $1: 8$ & $1: 1$ & - & + & $1: 1.024$ \\
\hline 6 & 9.2 & 1:32 & $1: 8$ & $1: 16$ & $1: 4$ & - & - & - & 1:8.192 \\
\hline 26 & 13.1 & - & - & - & - & - & - & - & $1: 1.024$ \\
\hline 73 & 12.8 & - & $1: 8$ & - & - & - & - & - & $1: 128$ \\
\hline
\end{tabular}

$4^{\circ} \mathrm{C}$ to $37^{\circ} \mathrm{C}$ and their activity disappeared when 2-mercaptoethanol was added to the serum, meaning that an anti-'i' IgM with polyclonal characteristics (kappa and lambda) was present.

The heterophil antibody titre was negative. Levels of antibodies against Epstein-Barr virus and Mycoplasma pneumoniae were below 1:8. High complement-fixing antibody titres against $\mathrm{CMV}$ $(1: 1,024)$ were found which increased two weeks later $(1: 8,192)$ with presence of CMV-specific IgM antibodies in both samples. CMV was simultaneously isolated from urine.

After warming up and administering packed red-blood-cell, the clinical situation improved. Seventeen days later (Table I), anti-'i' antibody titres had decreased, direct Coombs' antiglobulin test was negative and the patient was discharged. Five and sixteen months later anti-'i' antibodies were not detected, CMV was not isolated from the urine, CMV antibody titre was decreasing, and haematological values showed a return toward normal.

\section{Discussion}

Our patient developed a severe episode of haemolytic anaemia related to the development of a polyclonal IgM anti-'i' antibody during the course of CMV infection. There are several explanations for the development of this antibody. The clinical course and evolution are against the diagnosis of idiopathic cold-agglutinin disease. On the other hand, the polyclonal type of the $\operatorname{IgM}$ is against cold-reactive antibodies associated with lymphoproliferative diseases ${ }^{2}$ which are usually of monoclonal type.

An infectious disease appeared as the most likely cause of the haemolytic anaemia in this case. There was no evidence of infection by $M$. pneumoniae, Epstein-Barr virus, or hepatitis B virus. Although the presence of CMV in the urine is not sufficient evidence for a systemic CMV infection in an immunocompromised patient, there was serological evidence of a concomitant CMV infection in our case. Complement-fixation antibody titres against $\mathrm{CMV}$ and levels of activity against cord erythrocytes were chronologically related (Table I), which suggests that CMV infection was responsible for the haemolytic anaemia through the development of anti-'i' antibodies.

Although thrombocytopenia and haemolytic anaemia associated with congenital CMV infection are relatively frequent, ${ }^{11,12}$ the association between CMV infection and haemolysis is certainly exceptional in adults. ${ }^{6,8,13}$ Toghill et al. ${ }^{14}$ reported an association between haemolytic anaemia and hepatitis by CMV in two adults. Coombs ${ }^{15}$ later found pathological signs of disseminated CMV infection in a patient who had haemolysis. In 1970, Kantor and associates ${ }^{16}$ reported that serum from a patient with post-transfusional $\mathrm{CMV}$ infection strongly agglutinated cord erythrocytes at $4^{\circ} \mathrm{C}$. Harris and co-workers ${ }^{13}$ reported observing haemolytic anaemia in an adult who had CMV mononucleosis, but antibodies against the 'i' antigen were not described. Finally, Berlin et al. ${ }^{8}$ described the first case of CMV infection associated with mild haemolytic anaemia initiated by an anti-'i' antibody in a previously healthy adult.

To the best of our knowledge, our case is the first one described in English language publications associating severe haemolysis with CMV infection in an immunocompromised patient. The severity of the haemolytic anaemia induced by anti- $i$ ' antibodies is related to several factors: ${ }^{17,18}$ titres of antibodies, their ability to activate complement, and thermal amplitude. Titres of antibodies above $1: 100$, as in our case, are associated with severe haemolysis. ${ }^{18}$ Antibodies of the IgM class with a broad thermal amplitude were present in this case, favouring a more severe haemolysis.

Why anti-' $i$ ' antibodies are induced by CMV infection is not known. The haemolytic process in the present case was probably initiated by crossreacting anti-erythrocytic antibodies induced by the CMV. Another explanation is that ' $i$ ' antigen could reappear on immature erythrocytes released from the bone marrow during haemolytic processes due to other causes and stimulate the production of antibodies against it. ${ }^{8}$ This could have been the possible explanation in our patient who showed a 
regenerative bone marrow after receiving polychemotherapy for a multiple myeloma, but this possibility can be rejected in view of the close chronological relation between the haemolytic anaemia and CMV infection.

Independently of the pathogenetic mechanism involved, this case shows that severe haemolytic anaemia mediated by anti-' $i$ ' antibodies in immunocompromised adult patients can be related to CMV infection and must be differentiated from other causes of haemolysis associated with lymphoproliferative diseases.

\section{References}

1. Beutler, E. Hemolytic anemia due to infections with microorganisms. In: Williams, W.J., Beutler, E., Erslev, A.J. et al. (eds) Hematology, 2nd edition, McGraw-Hill, New York, 1977, pp 581-584.

2. Case Records of the Massachusetts General Hospital (Case 39-1983). N Engl J Med 1983, 309: 782-789.

3. Jenkins, W.J., Kosten, H.G., Marsh, W.L. et al. Infectious mononucleosis: an unsuspected source of anti-'i'. $B r J$ Haematol 1965, 11: 480-483.

4. Ho, M. Acquired cytomegalovirus infection and the mononucleosis syndrome, in Ho, M. (ed) Cytomegalovirus: Biology and Infection, Ist edition. Plenum Medical Book Co, New York, 1982, pp. 160-161.

5. Chessin, L.N. \& Magnussen, C.R. Infectious mononucleosis and mononucleosis-like syndromes. In Reese, R.E. \& Gordon Douglas, R. Jr (eds) A Practical Approach to Infectious Diseases, 1st edition. Boston, Little, Brown and Company, 1983, pp. 685-695.

6. Betts, R.F. Syndromes of cytomegalovirus infection. $A d v$ Intern Med 1980, 26: 447-466.

7. Nankervis, G.A. \& Kumar, M.L. Disease produced by cytomegalovirus. Med Clin North Am 1978, 62: 1021-1035.

8. Berlin, B.S., Chandler, R. \& Green, D. Anti-'i' antibody and hemolytic anemia associated with spontaneous cytomegalovirus mononucleosis. Am J Clin Pathol 1977, 67: 459-461.

9. Durie, B.G.M. \& Salmon, S.E. A clinical staging system for multiple myeloma: correlation of measured myeloma cell mass with presenting clinical features, response, treatment, and survival. Cancer 1975, 36: 842-854.

10. Case, D.C. Jr., Lee, III, B.J. \& Clarkson, B.D. Improved survival times in multiple myeloma treated with melphalan, prednisone, cyclophosphamide, vincristine, and BCNU: M-2 protocol. Am J Med 1977, 63: 897-903.

11. Zuelzer, W.W., Stulberg, C.S., Page, R.H. et al. The Emily Cooley lecture: Etiology and pathogenesis of acquired hemolytic anemia. Transfusion 1966, 6: 438-461.

12. Ho, M. Cytomegalovirus, In: Mandell, G.L., Gordon Douglas, R. \& Bennett, J.E. (eds) Principles and Practice of Infectious Diseases, 2nd edition. Wiley Medical Publication, New York 1985, pp. 960-970.

13. Harris, A.I., Meyer, R.J. \& Brody, E.A. Cytomegalovirusinduced thrombocytopenia and hemolysis in a adult. Ann Intern Med 1975, 83: 670-671.

14. Toghill, P.J., Bailey, M.E. Williams, R. et al. Cytomegalovirus hepatitis in the adult. Lancet 1967, i: 1351-1354.

15. Coombs, R.R.H. Cytomegalic inclusion-body disease associated with acquired autoimmune haemolytic anaemia. Br Med J 1968, 2: 743-744.

16. Kantor, G.L., Goldberg, L.S., Johnson, B.L. et al., Immunologic abnormalities induced by post-perfusion cytomegalovirus infection. Ann Intern Med 1970, 73: 553-558.

17. Atkinson, J.P., Rosse, W.F. Immunohematology, In: Pouker, Ch.W. (ed) Clinical Immunology W.B. Saunders, Philadelphia, 1980, pp. 930-981.

18. Adamson, J.W., Marder, V.J., Lessin, L.S. et al. Cold reactive antibody autoimmune hemolytic anemia. In: Dietschy, J.M. (ed) Haematology and Oncology, vol.6. The Science and Practice of Clinical Medicine Grune \& Stratton, New York, 1980, pp. 64-66. 